Bangladesh J. Bot. 49(4): 891-901, 2020 (December)

\title{
EFFECTS OF IRON AND PGPR ON ANTIOXIDANT STATUS AND SOME PHYSIOLOGICAL TRAITS OF TRITICALE UNDER DIFFERENT IRRIGATION LEVELS
}

\author{
Rana Ghasemi, Raouf Seyed Sharifi* and Younes Kheirizadeh Arough \\ Department of Agronomy and Plant Breeding, Faculty of Agriculture and Natural Resources, \\ University of Mohaghegh Ardabili, Ardabil, Iran
}

Keywords: Catalase, Electrical conductivity, Peroxidase, PGPR, Proline, Triticale, Water deficit

\begin{abstract}
A factorial experiment was conducted to study the effects of iron and plant growth promoting rhizobacteria (PGPR) on antioxidant status and some physiological traits of triticale under different irrigation levels. Experimental factors were included irrigation in three levels [(i) normal irrigation $\left(\mathrm{I}_{0}\right)$ as control; (ii) moderate water limitation $\left(\mathrm{I}_{1}\right)$ and (iii) severe water limitation $\left.\left(\mathrm{I}_{2}\right)\right]$. Three PGPR levels [(i) no PGPR $\left(\mathrm{P}_{0}\right)$, (ii) Psedomunas putida $\left(\mathrm{P}_{1}\right)$, (iii) Azospirillum lipoferum $\left.\left(\mathrm{P}_{2}\right)\right]$ and three nano iron oxide levels [(i) without nano iron oxide $\left(\mathrm{F}_{0}\right)$ as control, (ii) application of $0.3\left(\mathrm{~F}_{1}\right)$ and (iii) $\left.\left.0.6\left(\mathrm{~F}_{2}\right) \mathrm{g} / \mathrm{l}\right)\right]$. Results showed that water limitation decreased chlorophyll content, relative water content and grain yield of triticale. Whereas, electrical conductivity, proline content and the activity of catalase (CAT), peroxidase (POD), polyphenol oxidase (PPO) enzymes increased. However, inoculation of plants with PGPR and iron application improved these traits under water limitation condition and normal irrigation. Based on the results, it was concluded that the application of PGPR and iron can be a proper tool for increasing triticale yield under water limitation condition.
\end{abstract}

\section{Introduction}

Triticale is a man-made crop, being a hybrid by cross-fertilization of wheat (Triticum spp.) and rye (Secale spp.). Triticale, which is an interesting crop in the areas where environmental conditions limit the productivity of other cereals (Giunta et al. 1999).

Drought is prominent among the most important ecological factors that impact crop growth and productivity (Bagci et al. 2007). Many physiological processes in plants are impaired by drought stress, including photosynthesis, enzyme activity, membrane stability and ultimately growth (Valentovic et al. 2006). Growth reduction under drought stress has been studied in barley (Samarah 2005) and wheat (Rampino et al. 2006). De Ronde et al. (2004) demonstrated that proline accumulation in plants can enhance tolerance to abiotic stresses. Drought also induces free radicals affecting antioxidant defenses and reactive oxygen species (ROS) such as superoxide radicals, hydrogen peroxide and hydroxyl radicals resulting in oxidative stress. At high concentrations ROS can cause damage to various levels of organization, like initiate lipid peroxidation, membrane deterioration and degrade proteins, lipids and nucleic acids in plants (Nair et al. 2008).

The role of microorganisms in plant growth, nutrient management and biocontrol activity is well established. These beneficial microorganisms colonize in the rhizosphere of plants and promote growth of the plants through various direct and indirect mechanisms (Grover et al. 2011). Sandhya et al. (2010) reported that Pseudomonas inoculated maize plants showed increased antioxidant enzymes activity under drought stress. Ghorbanpour et al. (2013) reported that inoculation of Hyoscyamus niger plants with Pseudomonas stimulated the activities of antioxidant

*Author for correspondence: <Raouf_ssharifi@yahoo.com>. 
enzymes and increased proline accumulation. Nadeem et al. (2006) reported that inoculation of maize with PGPR increased the chlorophyll content.

Mineral nutrients are essential for plant growth through their fundamental roles in plant metabolism (Bagci et al. 2007). Iron is the first rare element recognized as necessary for plants and animals, playing an important role in biochemical and physiological processes. It works as a key enzyme co-factor that plays a role in plant hormone synthesis and is engaged in many electron transportation reactions (Kerkeb and Connolly 2006). Iron is critical for chlorophyll formation and photosynthesis and is important in the enzyme systems and respiration of plants.

A better understanding of triticale antioxidant status and physiological responses may help the programs with the objectives to improve the grain yield under water limitation. Therefore, the aim of this study was to evaluate the effects of PGPR and iron on the physiological responses of triticale under water limitation.

\section{Materials and Methods}

A factorial experiment based on RCBD with three replications was conducted under greenhouse condition in 2015. Experimental factors included irrigation in three levels [(i) normal irrigation $\left(\mathrm{I}_{0}\right)$ as control, (ii) moderate water limitation $\left(\mathrm{I}_{1}\right)$-irrigation with holding at $50 \%$ of heading stage and (iii) severe water limitation $\left(\mathrm{I}_{2}\right)$ - irrigation with holding at $50 \%$ of booting stage]. Three PGPR levels [(i) no PGPR $\left(\mathrm{P}_{0}\right)$, (ii) Psedomunas putida strain $9\left(\mathrm{P}_{1}\right)$ and (iii) Azospirillum lipoferum strain $\left.\mathrm{OF}\left(\mathrm{P}_{2}\right)\right]$ and three nano iron oxide levels [(i) (without nano iron oxide $\left(\mathrm{F}_{0}\right)$ as control, (ii) application of $0.3\left(\mathrm{~F}_{1}\right)$ and (iii) $\left.0.6\left(\mathrm{~F}_{2}\right) \mathrm{g} / \mathrm{l}\right)$ ]. The soil was silty loam, with $\mathrm{pH}$ about 6.9. Air temperature ranged from $23-26^{\circ} \mathrm{C}$ during the day and $18-20^{\circ} \mathrm{C}$ during the night. Humidity ranged from $65 \pm 7 \%$. The triticale cultivar 'Joanilo' was used in the present experiment. Optimal density of cultivar 'Joanilo' is 400 seeds $^{-2}$, so fifty seeds of triticale were sown in each prepared pot and filled approximately with $22 \mathrm{~kg}$ of above mentioned soil. The experiment was carried out on the soil with a texture of silty loam, with $\mathrm{pH}$ about 7.8 , total organic C- $0.62 \mathrm{~g} / \mathrm{kg}$ soil, $\mathrm{Fe}-8.6 \mathrm{mg} / \mathrm{kg}$. The pots were immediately irrigated after planting. Psedomunas putida strain 9 and Azospirillum lipoferum strain OF were isolated from the rhizospheres of wheat by Research Institute of Soil and Water, Tehran, Iran. The strains and cell densities of microorganisms used as PGPR in this experiment were $1 \times 10^{7} \mathrm{cfu}$. Foliar application with nano iron oxide was done in two stages of growth ( 3 - 4 leaf stage and before booting stage).

Samples were placed in aluminum foil and transported from the greenhouse on ice bath. CAT, POD and PPO activity was assayed according to Karo and Mishra (1976).

Relative water content was measured following the formula of Che Lah et al. (2011).

Electrical conductivity of flag leaves was calculated following the standard method of Jodeh et al. (2015) at room temperature of $23 \pm 1^{\circ} \mathrm{C}$ using an electrical-conductivity meter.

A portable chlorophyll meter (SPAD-502; Konica Minolta Sensing, Inc., Japan) was used to measure the leaf greenness of the triticale plants. For each plant, measurements were taken at three locations of each leaf, two on each side of the midrib of flag leaves, and then averaged. Proline was measured following the method of Bates et al. (1973).

In order to measure grain yield per plant, 10 plants of each pot randomly harvested and then the grains were collected. Analysis of variance and mean comparisons were performed using SAS ver 9.1 computer software packages. The main effects and interactions were tested using the least significant difference (LSD) test at the 0.05 probability level. 


\section{Results and Discussion}

Analysis of variance showed a significant interaction effect between irrigation and PGPR on chlorophyll index, electrical conductivity and PPO activity (Table 1). Interaction of irrigation levels and nano iron oxide significantly affected all traits (except PPO activity and grain yield) (Table 1). Also all traits (except RWC) were affected by the interaction of PGPR and nano iron oxide (Table 1). There were significant interactions between irrigation, PGPR and nano iron oxide on electrical conductivity, proline, POD activity and grain yield. The activity of CAT, POD and

Table 1. Means comparison and variance analysis effects of PGPR and nano iron oxide on chlorophyll index, electrical conductivity, proline content, activity of CAT, POD and PPO enzymes, relative water content and grain yield of triticale under water limitation.

\begin{tabular}{|c|c|c|c|c|c|c|c|c|}
\hline & $\begin{array}{l}\text { Chloro- } \\
\text { phyll } \\
\text { index }\end{array}$ & $\begin{array}{c}\text { Electrical } \\
\text { conductivity } \\
(\mu \mathrm{S} / \mathrm{cm})\end{array}$ & $\begin{array}{c}\text { Proline } \\
(\mu \mathrm{g} / \mathrm{g} \\
\mathrm{FW})\end{array}$ & $\begin{array}{l}\text { CAT (OD } \\
\mu \mathrm{g} \text { protein/ } \\
\text { min) }\end{array}$ & $\begin{array}{l}\text { POD } \\
(\mathrm{OD} \mu \mathrm{g} \\
\text { protein/ } \\
\text { min })\end{array}$ & $\begin{array}{c}\mathrm{PPO} \\
(\mathrm{OD} \mu \mathrm{g} \\
\text { protein/ } \\
\mathrm{min})\end{array}$ & $\begin{array}{c}\text { Relative } \\
\text { water } \\
\text { content } \\
(\%)\end{array}$ & $\begin{array}{c}\text { Grain } \\
\text { yield } \\
\text { (g/plant) }\end{array}$ \\
\hline \multicolumn{9}{|l|}{ Irrigation levels } \\
\hline $\begin{array}{l}\mathrm{I}_{0}=\text { Normal } \\
\text { irrigation }\end{array}$ & $53.5 \mathrm{a}$ & $48.95 \mathrm{c}$ & $6.37 \mathrm{c}$ & $3.83 \mathrm{c}$ & $3.87 \mathrm{c}$ & $3.07 \mathrm{c}$ & $82.33 \mathrm{a}$ & $1.77 \mathrm{a}$ \\
\hline $\begin{array}{l}\mathrm{I}_{1=} \text { Moderate } \\
\text { water limitation }\end{array}$ & $50.5 \mathrm{~b}$ & $53.01 \mathrm{~b}$ & $6.64 \mathrm{~b}$ & $4.75 \mathrm{~b}$ & $4.21 \mathrm{~b}$ & $3.38 \mathrm{~b}$ & $75.45 \mathrm{~b}$ & $1.58 \mathrm{~b}$ \\
\hline $\begin{array}{l}\mathrm{I}_{2}=\text { Severe water } \\
\text { limitation }\end{array}$ & $46 \mathrm{c}$ & $58.71 \mathrm{a}$ & $6.96 \mathrm{a}$ & $5.5 \mathrm{a}$ & $4.95 \mathrm{a}$ & $3.7 \mathrm{a}$ & $71.03 \mathrm{c}$ & $1.44 \mathrm{c}$ \\
\hline \multicolumn{9}{|c|}{ Nano iron oxide $(g / l)$} \\
\hline $\begin{array}{l}\mathrm{F}_{0}=\text { Without iron } \\
\text { as control }\end{array}$ & $45.3 \mathrm{c}$ & $59 \mathrm{a}$ & $6.43 \mathrm{~b}$ & $3.4 \mathrm{c}$ & $3.03 \mathrm{c}$ & $2.26 \mathrm{c}$ & $71.13 \mathrm{c}$ & $1.32 \mathrm{c}$ \\
\hline$F_{1}=0.3$ & $49.4 \mathrm{~b}$ & $52.14 \mathrm{~b}$ & $6.44 \mathrm{~b}$ & $4.15 \mathrm{~b}$ & $3.99 \mathrm{~b}$ & $3.5 \mathrm{~b}$ & $74.71 \mathrm{~b}$ & $1.47 \mathrm{~b}$ \\
\hline $\mathrm{F}_{2}=0.6$ & $55.4 \mathrm{a}$ & $49.54 \mathrm{c}$ & $7.1 \mathrm{a}$ & $6.53 \mathrm{a}$ & $6.01 \mathrm{a}$ & $4.39 \mathrm{a}$ & $82.96 \mathrm{a}$ & $2.02 \mathrm{a}$ \\
\hline \multicolumn{9}{|l|}{ PGPR } \\
\hline $\begin{array}{l}\mathrm{P}_{0=} \text { No inocula- } \\
\text { tion as control }\end{array}$ & $45.8 \mathrm{c}$ & $58.66 \mathrm{a}$ & $6.04 \mathrm{c}$ & $2.85 \mathrm{c}$ & $2.48 \mathrm{c}$ & $1.97 \mathrm{c}$ & $72.29 \mathrm{c}$ & $1.2 \mathrm{c}$ \\
\hline $\mathrm{P}_{1}=$ Psedomunas & $51 \mathrm{~b}$ & $52.19 \mathrm{~b}$ & $7.14 \mathrm{a}$ & $5.18 \mathrm{~b}$ & $5.15 \mathrm{~b}$ & $4.27 \mathrm{a}$ & $79.68 \mathrm{a}$ & $1.69 \mathrm{~b}$ \\
\hline $\mathrm{P}_{2}=$ Azospirillum & $53.2 \mathrm{a}$ & $49.83 \mathrm{c}$ & $6.79 \mathrm{~b}$ & $6.06 \mathrm{a}$ & $5.41 \mathrm{a}$ & $3.91 \mathrm{~b}$ & $76.84 \mathrm{~b}$ & $1.91 \mathrm{a}$ \\
\hline $\mathrm{I} * \mathrm{~F}$ & $*$ & $* *$ & $* *$ & $* *$ & $* *$ & ns & $* *$ & $\mathrm{~ns}$ \\
\hline $\mathrm{I} * \mathrm{P}$ & $* *$ & $* *$ & $\mathrm{~ns}$ & ns & $* *$ & ns & ns & ns \\
\hline $\mathrm{F} * \mathrm{P}$ & $*$ & $* *$ & $* *$ & $* *$ & $* *$ & $* *$ & $\mathrm{~ns}$ & $* *$ \\
\hline $\mathrm{I} * \mathrm{~F} * \mathrm{P}$ & ns & $* *$ & $* *$ & $\mathrm{~ns}$ & $* *$ & $\mathrm{~ns}$ & $\mathrm{~ns}$ & $* *$ \\
\hline $\mathrm{CV}$ & 2.8 & 2.76 & 1.92 & 9.07 & 9.07 & 8.52 & 3.67 & 6.01 \\
\hline
\end{tabular}

The same letters in each column show non-significant difference at $\mathrm{p} \leq 0.05$ by LSD test. (ns) and $(*, * *)$ show no significant and significant differences at $0.05,0.01$ probability level, respectively. CV: Coefficient of variation; CAT: Catalase; POD: Peroxidase and PPO: Polyphenol oxidase.

PPO enzymes increased as water limitation increased. The highest content of CAT $(5.5,6.06$ and $6.53 \mathrm{OD} \mu \mathrm{g}$ protein $/ \mathrm{min})$ and POD $(4.95,5.41$ and $6.01 \mathrm{OD} \mu \mathrm{g}$ protein $/ \mathrm{min})$ were observed in severe water limitation, application of Azospirillum and $0.6 \mathrm{~g} / \mathrm{l}$ nano iron oxide, respectively (Table 1). The lowest of CAT (3.83, 2.85 and $3.4 \mathrm{OD} \mu \mathrm{g}$ protein/min) and POD activity (3.87, 2.48 and $3.03 \mathrm{OD} \mu \mathrm{g}$ protein $/ \mathrm{min}$ ) were obtained at $\mathrm{I}_{0}, \mathrm{P}_{0}$ and $\mathrm{F}_{0}$ (Table 1). The maximum content of PPO (3.7, 4.27 and $4.39 \mathrm{OD} \mu \mathrm{g}$ protein $/ \mathrm{min}$ ) reached in severe water limitation, application of Psedomunas and $0.6 \mathrm{~g} / \mathrm{l}$ nano iron oxide, respectively (Table 1). The lowest of PPO (3.07, 1.97 
and $2.26 \mathrm{OD} \mu \mathrm{g}$ protein/min) were obtained at $\mathrm{I}_{0}, \mathrm{P}_{0}$ and $\mathrm{F}_{0}$ (Table 1). Inoculation with the PGPR under water limitation, significantly increased CAT, POD and PPO enzymes activity of triticale and also the antioxidant enzymes activity increased when nano iron oxide was applied. Interaction effect between nano iron oxide and PGPR showed that the highest content of CAT (8.03 OD $\mu \mathrm{g}$ protein/min) and $\mathrm{PPO}\left(5.0 \mathrm{OD} \mu \mathrm{g}\right.$ protein/min) were obtained in $\mathrm{F}_{2} \mathrm{P}_{2}$ and the lowest of the mentioned traits (2.12 and $1.19 \mathrm{OD} \mu \mathrm{g}$ protein $/ \mathrm{min}$, respectively) were observed in $\mathrm{F}_{0} \mathrm{P}_{0}$ (Table 2). The interaction effect between water limitation and nano iron oxide showed that the highest content of CAT (7.7 OD $\mu \mathrm{g}$ protein/min) was found in $\mathrm{I}_{2} \mathrm{~F}_{2}$. The lowest of it $(2.84 \mathrm{OD} \mu \mathrm{g}$ protein/min) was obtained in $\mathrm{I}_{0} \mathrm{~F}_{0}$ (Table 3). Interaction effect between water limitation $\times$ PGPR $\times$ nano iron oxide showed that the highest content of POD $(8.52 \mathrm{OD} \mu \mathrm{g}$ protein $/ \mathrm{min})$ was observed in $\mathrm{I}_{2} \mathrm{P}_{1} \mathrm{~F}_{2}$ (Table 4). While, the lowest of it $\left(1.31 \mathrm{OD} \mu \mathrm{g}\right.$ protein $/ \mathrm{min}$ ) was obtained at $\mathrm{I}_{0} \mathrm{P}_{0} \mathrm{~F}_{0}$ (Table 4). Exposure of plants to unfavorable environmental conditions such as drought, salinity, temperature extremes and nutrient deficiency can increase the production of ROS (e.g., O2$\mathrm{H}_{2} \mathrm{O}_{2}$, OH and ${ }^{1} \mathrm{O}_{2}$ ) (Singh et al. 2008). ROS are highly reactive molecules and can damage cell structures such as carbohydrates, nucleic acids, lipids, and proteins and alter their functions. In order to overcome these effects, plants develop antioxidant defense systems comprising both enzymatic and non-enzymatic components that serve to prevent ROS accumulation and alleviate the oxidative damage occurring during drought stress (Miller et al. 2010).

Table 2. Effects of nano iron oxide $\times$ PGPR on CAT and PPO activity.

\begin{tabular}{|c|c|c|c|c|c|c|}
\hline \multirow{2}{*}{ Treatments } & \multicolumn{3}{|c|}{ CAT (OD $\mu \mathrm{g}$ protein/min) } & \multicolumn{3}{|c|}{ PPO (OD $\mu \mathrm{g}$ protein/min) } \\
\hline & $\mathrm{F}_{0}$ & $\mathrm{~F}_{1}$ & $\mathrm{~F}_{2}$ & $\mathrm{~F}_{0}$ & $\mathrm{~F}_{1}$ & $\mathrm{~F}_{2}$ \\
\hline $\mathrm{P}_{0}$ & $2.12 \mathrm{~d}$ & $2.33 \mathrm{~d}$ & $4.1 \mathrm{c}$ & $1.19 \mathrm{e}$ & $1.4 \mathrm{e}$ & $3.32 \mathrm{c}$ \\
\hline $\mathrm{P}_{1}$ & $3.95 \mathrm{c}$ & $4.12 \mathrm{c}$ & $7.46 \mathrm{a}$ & $3.15 \mathrm{c}$ & $4.64 \mathrm{ab}$ & $4.85 \mathrm{a}$ \\
\hline $\mathrm{P}_{2}$ & $4.14 \mathrm{c}$ & $5.99 \mathrm{~b}$ & $8.03 \mathrm{a}$ & $2.44 \mathrm{~d}$ & $4.45 b$ & $5.0 \mathrm{a}$ \\
\hline $\mathrm{LSD}_{0.05}$ & \multicolumn{3}{|c|}{0.84} & \multicolumn{3}{|c|}{0.39} \\
\hline
\end{tabular}

Means with similar letters are not significantly different at $\mathrm{p} \leq 0.05$ by LSD test.

Table 3. Effects of irrigation $\times$ nano iron oxide on CAT activity.

\begin{tabular}{cccc}
\hline \multirow{2}{*}{ Treatments } & \multicolumn{3}{c}{ CAT $(\mathrm{OD} \mu \mathrm{g}$ protein/min) } \\
\cline { 2 - 4 } & $\mathrm{F}_{0}$ & $\mathrm{~F}_{1}$ & $\mathrm{~F}_{2}$ \\
\hline $\mathrm{I}_{0}$ & $2.84 \mathrm{~d}$ & $3.56 \mathrm{~cd}$ & $5.09 \mathrm{~b}$ \\
$\mathrm{I}_{1}$ & $3.31 \mathrm{~cd}$ & $4.15 \mathrm{bcd}$ & $6.8 \mathrm{a}$ \\
$\mathrm{I}_{2}$ & $4.06 \mathrm{bcd}$ & $4.74 \mathrm{bc}$ & $7.7 \mathrm{a}$ \\
\hline $\mathrm{LSD}_{0.05}$ & & 1.48 & \\
\hline
\end{tabular}

Means with similar letters are not significantly different at $\mathrm{p} \leq 0.05$ by LSD test.

Enzymatic components include CAT, POD, SOD and PPO (Kaushal and Wani 2016). An increase in POD activity was also observed by different authors during drought and salt stress (Wang et al. 2012). Wang et al. (2012) found that application of PGPR strains improved plant enzyme activity, which alleviates the oxidative damage induced by drought and salinity. Iron role in the activity of some enzymes such as catalase, peroxidase and cytochrome oxidase has been 
shown (Blakrishman 2000). Iron as a cofactor involved in the structure of many antioxidant enzymes and results indicate that lack of micro-nutrients elements, antioxidant enzyme activity decreased and therefore the sensitivity of plants to environmental stresses will increase (Kaviani et al. 2016).

Table 4. Effects of irrigation $\times$ PGPR $\times$ nano iron oxide on POD activity.

\begin{tabular}{ccccc}
\hline Treatments & \multicolumn{3}{c}{ POD $(\mathrm{OD} \mu \mathrm{g}$ protein/min $)$} \\
\hline \multirow{3}{*}{$\mathrm{I}_{0}$} & & $\mathrm{~F}_{0}$ & $\mathrm{~F}_{1}$ & $\mathrm{~F}_{2}$ \\
\cline { 3 - 5 } & $\mathrm{P}_{0}$ & $1.31 \mathrm{i}$ & $1.39 \mathrm{i}$ & $3.29 \mathrm{jk}$ \\
& $\mathrm{P}_{1}$ & $1.63 \mathrm{i}$ & $1.94 \mathrm{i}$ & $3.7 \mathrm{ijk}$ \\
\multirow{2}{*}{$\mathrm{I}_{1}$} & $\mathrm{P}_{2}$ & $1.5 \mathrm{i}$ & $1.73 \mathrm{i}$ & $3.85 \mathrm{hij}$ \\
& $\mathrm{P}_{0}$ & $4.46 \mathrm{fgh}$ & $5.18 \mathrm{de}$ & $5.99 \mathrm{bc}$ \\
& $\mathrm{P}_{1}$ & $5.52 \mathrm{~cd}$ & $4.97 \mathrm{def}$ & $6.21 \mathrm{~b}$ \\
& $\mathrm{P}_{2}$ & $4.25 \mathrm{ghi}$ & $5.23 \mathrm{de}$ & $6.47 \mathrm{~b}$ \\
$\mathrm{I}_{2}$ & $\mathrm{P}_{0}$ & $3.18 \mathrm{k}$ & $4.92 \mathrm{def}$ & $6.06 \mathrm{ghi}$ \\
& $\mathrm{P}_{1}$ & $4.14 \mathrm{ghi}$ & $5.03 \mathrm{def}$ & $8.52 \mathrm{a}$ \\
& $\mathrm{P}_{2}$ & $4.66 \mathrm{efg}$ & $5.49 \mathrm{~cd}$ & $8.46 \mathrm{a}$ \\
\hline $\mathrm{LSD}_{0.05}$ & \multicolumn{4}{c}{0.64} \\
\hline
\end{tabular}

Means with similar letters are not significantly different at $\mathrm{p} \leq 0.05$ by LSD test.

The proline content significantly increased under water limitation condition. Inoculation with PGPR under water limitation increased proline of triticale. In addition, the proline content significantly increased when nano iron oxide was applied. Results showed that the highest content of proline $(7.75 \mu \mathrm{g} / \mathrm{g} \mathrm{FW})$ was obtained in severe water limitation, application of Psedomunas and $0.6 \mathrm{~g} / \mathrm{l}$ nano iron oxide (Table 5). The minimum of proline $(5.30 \mu \mathrm{g} / \mathrm{g} \mathrm{FW})$ was obtained in $\mathrm{I}_{0} \mathrm{P}_{0} \mathrm{~F}_{0}$ (Table 5). There was an increase of $9.46 \%$ in content of proline in the $\mathrm{I}_{2} \mathrm{P}_{1} \mathrm{~F}_{2}$ in comparison with $\mathrm{I}_{2} \mathrm{P}_{0} \mathrm{~F}_{0}$ (Table 5). Proline has a function of osmotic adjustment in plants, but it also protects enzymes and membranes against oxidative stress (Agarwal and Pandey 2004). Indeed, proline has been demonstrated to confer drought stress tolerance to wheat plants by increasing the antioxidant system rather than increasing osmotic adjustment (Szabados and Savoure 2009). PGPRs consortia alleviated drought stress in rice plants by accumulation of proline in rice plants grown under drought there by improving the plant growth (Gusain et al. 2015). The electrical conductivity significantly increased under water limitation condition. Inoculation with PGPR under water limitation decreased electrical conductivity of triticale. In addition, the electrical conductivity content significantly decreased when nano iron oxide was applied. The highest content of electrical conductivity $(76.09 \mu \mathrm{S} / \mathrm{cm})$ was obtained in $\mathrm{I}_{2} \mathrm{P}_{0} \mathrm{~F}_{0}$ (Table 5) and the lowest of it (45.06 $\mu \mathrm{S} / \mathrm{cm}$ ) was obtained in $\mathrm{I}_{0} \mathrm{P}_{2} \mathrm{~F}_{2}$ (Table 5). There was a decrease of $26.14 \%$ in content of electrical conductivity in the $\mathrm{I}_{2} \mathrm{P}_{2} \mathrm{~F}_{2}$ in comparison with $\mathrm{I}_{2} \mathrm{P}_{0} \mathrm{~F}_{0}$ (Table 5). Cell membrane is one of the first targets of plant stresses and the ability of plants to maintain membrane integrity under drought is what determines tolerance towards drought. Under water deficit, cell membrane subjects to changes such as penetrability and decrease in sustainability (Blokina et al. 2003). Alexiva et al. (2001) reported that drought and ultra violet stress in pea and wheat plant through amplifying of reactive oxygen species production increased electrolyte leakage. Inoculation with PGPR 
decreased electrolyte leakage compared to un-inoculated seedlings under drought stress (Sandhya et al. 2010). Bacteria mediated changes in the elasticity of the root cell membranes is one of the first steps towards enhanced tolerance to water deficiency (Dimkpa et al. 2009). PGPR improves the stability of plant cell membranes by activating the antioxidant defense system, enhancing drought tolerance in plants (Gusain et al. 2015).

Table 5. Effects of irrigation $\times$ PGPR $\times$ nano iron oxide on proline and electrical conductivity of triticale.

\begin{tabular}{|c|c|c|c|c|c|c|c|}
\hline \multicolumn{2}{|c|}{ Treatments } & \multicolumn{3}{|c|}{ Proline $(\mu \mathrm{g} / \mathrm{g}$ FW) } & \multicolumn{3}{|c|}{ Electrical conductivity $(\mu \mathrm{S} / \mathrm{cm})$} \\
\hline & & $\mathrm{F}_{0}$ & $\mathrm{~F}_{1}$ & $\mathrm{~F}_{2}$ & $\mathrm{~F}_{0}$ & $\mathrm{~F}_{1}$ & $\mathrm{~F}_{2}$ \\
\hline \multirow{3}{*}{$\mathrm{I}_{0}$} & $\mathrm{P}_{0}$ & $5.3 \mathrm{~m}$ & $5.38 \mathrm{~m}$ & $6.47 \mathrm{hi}$ & $48.9 \mathrm{jkl}$ & $46.9 \mathrm{lmn}$ & $49.7 \mathrm{ijk}$ \\
\hline & $\mathrm{P}_{1}$ & $6.6 \mathrm{gh}$ & $6.84 \mathrm{f}$ & $6.78 \mathrm{fg}$ & $49.17 \mathrm{ijkl}$ & $47.9 \mathrm{klm}$ & $45.9 \mathrm{mn}$ \\
\hline & $\mathrm{P}_{2}$ & $6.35 \mathrm{ij}$ & $6.09 \mathrm{k}$ & $6.21 \mathrm{jk}$ & $47.3 \mathrm{klmn}$ & $45.2 \mathrm{n}$ & $45.06 \mathrm{n}$ \\
\hline \multirow{3}{*}{$\mathrm{I}_{1}$} & $\mathrm{P}_{0}$ & $5.74 \mathrm{i}$ & $5.69 \mathrm{i}$ & $6.68 \mathrm{fgh}$ & $66.7 \mathrm{~b}$ & $54.03 \mathrm{fg}$ & $52.62 \mathrm{gh}$ \\
\hline & $\mathrm{P}_{1}$ & $6.11 \mathrm{k}$ & $7.06 \mathrm{de}$ & $6.88 \mathrm{ef}$ & $58.7 \mathrm{~d}$ & $51.4 \mathrm{hi}$ & $51.07 \mathrm{hij}$ \\
\hline & $\mathrm{P}_{2}$ & $6.77 \mathrm{fg}$ & $6.25 \mathrm{jk}$ & $7.16 \mathrm{~cd}$ & 50.7 hij & 50.4 hij & $47.2 \mathrm{lmn}$ \\
\hline \multirow{3}{*}{$\mathrm{I}_{2}$} & $\mathrm{P}_{0}$ & $7.08 \mathrm{de}$ & $7.1 \mathrm{~d}$ & $7.22 \mathrm{~cd}$ & $76.09 \mathrm{a}$ & $62.8 \mathrm{c}$ & $58.76 \mathrm{~d}$ \\
\hline & $\mathrm{P}_{1}$ & $7.14 \mathrm{~cd}$ & $7.26 \mathrm{bcd}$ & $7.75 \mathrm{a}$ & $64.7 \mathrm{bc}$ & $52.46 \mathrm{gh}$ & $52.3 \mathrm{gh}$ \\
\hline & $\mathrm{P}_{2}$ & $7.35 \mathrm{bc}$ & $7.12 \mathrm{~d}$ & $7.45 \mathrm{~b}$ & $58.36 \mathrm{de}$ & $55.7 \mathrm{f}$ & $56.2 \mathrm{ef}$ \\
\hline \multicolumn{2}{|c|}{$\mathrm{LSD}_{0.05}$} & & 0.21 & & & 2.42 & \\
\hline
\end{tabular}

Means with similar letters are not significantly different at $\mathrm{p} \leq 0.05$ by LSD test.

Table 6. Effects of irrigation $\times$ nano iron oxide on RWC.

\begin{tabular}{cccc}
\hline Treatments & \multicolumn{3}{c}{ Relative water content (RWC\%) } \\
\hline & $\mathrm{F}_{0}$ & $\mathrm{~F}_{1}$ & $\mathrm{~F}_{2}$ \\
\cline { 2 - 4 } $\mathrm{I}_{0}$ & $80.13 \mathrm{~b}$ & $80.63 \mathrm{~b}$ & $86.78 \mathrm{a}$ \\
$\mathrm{I}_{1}$ & $69.28 \mathrm{~d}$ & $79.59 \mathrm{~b}$ & $81.98 \mathrm{~b}$ \\
$\mathrm{I}_{2}$ & $63.5 \mathrm{e}$ & $69.46 \mathrm{~d}$ & $75.1 \mathrm{c}$ \\
\hline $\mathrm{LSD}_{0.05}$ & & 3.92 & \\
\hline
\end{tabular}

Means with similar letters are not significantly different at $\mathrm{p} \leq 0.05$ by LSD test.

Zago and Oteiza (2001) stated that iron element by increasing the activity of antioxidant systems in plants decreased reactive oxygen species injuries and plays an important role in membrane stability. Interaction effect between nano iron oxide and water limitation showed that the highest content of relative water content $(86.78 \%)$ was obtained in normal irrigation and 0.6 $\mathrm{g} / \mathrm{l}$ nano iron oxide (Table 6). The minimum of its value (63.5\%) was obtained in $\mathrm{I}_{2} \mathrm{~F}_{0}$ (Table 6). There was an increase of $18.27 \%$ in content of relative water content in the $\mathrm{I}_{2} \mathrm{~F}_{2}$ in comparison with $\mathrm{I}_{2} \mathrm{~F}_{0}$ (Table 6). The decrease in leaf relative water content could be related to low water availability under stress conditions or to root systems, which are not able to compensate for water lost by transpiration through a reduction of the absorbing surface (Gadallah 2000). Sadeghipour and Aghaei (2012) showed that drought stress conditions significantly reduced the leaf relative water content. Shaharoona et al. (2006) reported that the inoculation treatment with PGPR isolates 
increased RWC from 5 - 16\% under normal and 21.7 - 28.4\% under stress conditions as compared to the un-inoculated control. The water limitation, PGPR and nano iron oxide significantly affected the chlorophyll index. Interaction effect between nano iron oxide and water limitation showed that the highest chlorophyll index (58.3) was obtained in $\mathrm{I}_{0} \mathrm{~F}_{2}$ (Table 7). The lowest of it (41.4) was obtained in $\mathrm{I}_{2} \mathrm{~F}_{0}$ (Table 7). There was an increase of $23.18 \%$ in chlorophyll index in the $\mathrm{I}_{2} \mathrm{~F}_{2}$ in comparison with $\mathrm{I}_{2} \mathrm{~F}_{0}$ (Table 7). Means comparison the effects of nano iron oxide and PGPR showed that the highest chlorophyll (58.2) was obtained in $\mathrm{P}_{2} \mathrm{~F}_{2}$ (Table 8). The lowest of it (40.2) was obtained in $\mathrm{P}_{0} \mathrm{~F}_{0}$ (Table 8). There was an increase of $26.80 \%$ in chlorophyll index in the $\mathrm{P}_{2} \mathrm{~F}_{2}$ in comparison with $\mathrm{P}_{2} \mathrm{~F}_{0}$ and increase of $13.23 \%$ in SPAD in the $\mathrm{P}_{2} \mathrm{~F}_{2}$ in comparison with $\mathrm{P}_{0} \mathrm{~F}_{2}$ (Table 8). Also, interaction effect between water limitation and PGPR showed that the highest chlorophyll index (56.0) was obtained in $\mathrm{I}_{0} \mathrm{P}_{2}$ (Table 9). The lowest of it (40.5) was obtained in $\mathrm{I}_{2} \mathrm{P}_{0}$ (Table 9). There was an increase of $15.30 \%$ in chlorophyll index in the $\mathrm{I}_{2} \mathrm{~F}_{2}$ in comparison with $\mathrm{I}_{2} \mathrm{~F}_{0}$ and decrease $16.60 \%$ in SPAD in the $\mathrm{I}_{2} \mathrm{P}_{2}$ in comparison with $\mathrm{I}_{0} \mathrm{P}_{2}$ (Table 9). Water limitation caused the reduction in chlorophyll index, while application of PGPR and nano iron oxide increased this trait values. Drought stress leads to increase reactive oxygen species production in plants resulted in decreasing of chlorophyll index, indicating the extent of the oxidative damages. This decrease may be also due to inhibition of chlorophyll biosynthesis pathway (Lalinia et al. 2012). Also, the reduction in chlorophyll content under drought stress has been considered as a typical symptom of oxidative stress and may be the result of pigment photooxidation and chlorophyll degradation (Oraki et al. 2012).

Table 7. Effects of Irrigation $\times$ nano iron oxide on chlorophyll index.

\begin{tabular}{cccc}
\hline Treatments & & Chlorophyll index & \\
\hline & $\mathrm{F}_{0}$ & $\mathrm{~F}_{1}$ & $\mathrm{~F}_{2}$ \\
\cline { 2 - 4 } $\mathrm{I}_{0}$ & $49.5 \mathrm{~b}$ & $52.8 \mathrm{~b}$ & $58.3 \mathrm{a}$ \\
$\mathrm{I}_{1}$ & $45.7 \mathrm{c}$ & $49.7 \mathrm{~b}$ & $56.8 \mathrm{a}$ \\
$\mathrm{I}_{2}$ & $41.4 \mathrm{~d}$ & $44.9 \mathrm{c}$ & $51 \mathrm{~b}$ \\
\hline $\mathrm{LSD}_{0.05}$ & & 3.5 & \\
\hline
\end{tabular}

Means with similar letters are not significantly different at $\mathrm{p} \leq 0.05$ by LSD test.

Table 8. Effects of nano iron oxide $\times$ PGPR on chlorophyll index.

\begin{tabular}{cccc}
\hline Treatments & \multicolumn{3}{c}{ Chlorophyll content } \\
\hline & $\mathrm{F}_{0}$ & $\mathrm{~F}_{1}$ & $\mathrm{~F}_{2}$ \\
\cline { 2 - 4 } $\mathrm{P}_{0}$ & $40.2 \mathrm{~d}$ & $49.4 \mathrm{bc}$ & $51.4 \mathrm{~b}$ \\
$\mathrm{P}_{1}$ & $46.3 \mathrm{c}$ & $50.1 \mathrm{~b}$ & $56.6 \mathrm{a}$ \\
$\mathrm{P}_{2}$ & $45.9 \mathrm{c}$ & $52.2 \mathrm{~b}$ & $58.2 \mathrm{a}$ \\
\hline LSD $_{0.05}$ & & 3.48 & \\
\hline
\end{tabular}

Means with similar letters are not significantly different at $\mathrm{p} \leq 0.05$ by LSD test.

Several studies reported that chlorophyll content is higher in plants treated with biofertilizer (Belimov et al. 2009). It is known that a low Fe supply negatively affects the chlorophyll content and other components of chloroplasts, which reduces growth capacity (De La Guardia and 
Alcantara 2002). Iron increased SPAD values. This is because iron functions as a component of proteins in significant cellular events such as respiration and cell division; moreover, it has a role in the reduction steps of important biological events, such as transpiration and photosynthesis, and also in chlorophyll biosynthesis (Zocchi et al. 2007).

Grain yield decreased as a result of moderate and severe water limitaion. Grain yield increased as result of application of PGPR and nano iron oxide under normal irrigation and water limitation. Means comparison showed that maximum of grain yield $(2.341 \mathrm{~g}$ per plant $)$ was observed in normal irrigation and application of Azospirillum and $0.6 \mathrm{~g} / \mathrm{l}$ nano iron oxide (Table 10). The lowest of yield ( $0.823 \mathrm{~g}$ per plant) was obtained in $\mathrm{I}_{2} \mathrm{P}_{0} \mathrm{~F}_{0}$ (Table 10).

Table 9. Effects of irrigation $\times$ PGPR on chlorophyll index of triticale.

\begin{tabular}{cccc}
\hline Treatments & \multicolumn{3}{c}{ Chlorophyll index } \\
\hline & $\mathrm{P}_{0}$ & $\mathrm{P}_{1}$ & $\mathrm{P}_{2}$ \\
\cline { 2 - 4 } $\mathrm{I}_{0}$ & $50.3 \mathrm{bc}$ & $54.3 \mathrm{ab}$ & $56.0 \mathrm{a}$ \\
$\mathrm{I}_{1}$ & $50 \mathrm{bc}$ & $51 \mathrm{bc}$ & $53.8 \mathrm{ab}$ \\
$\mathrm{I}_{2}$ & $40.5 \mathrm{~d}$ & $47.7 \mathrm{c}$ & $46.7 \mathrm{c}$ \\
\hline $\mathrm{LSD}_{0.05}$ & & 4.44 & \\
\hline
\end{tabular}

Means with similar letters are not significantly different at $\mathrm{p} \leq 0.05$ by LSD test.

Table 10. Effects of PGPR $\times$ nano iron oxide on grain yield of triticale under water limitation.

\begin{tabular}{ccccc}
\hline \multicolumn{2}{c}{ Treatments } & \multicolumn{3}{c}{ Grain yield (g per plant) } \\
\hline & & $\mathrm{F}_{0}$ & $\mathrm{~F}_{1}$ & $\mathrm{~F}_{2}$ \\
\cline { 3 - 5 } $\mathrm{I}_{0}$ & $\mathrm{P}_{0}$ & $1.892 \mathrm{def}$ & $2.045 \mathrm{bcd}$ & $2.115 \mathrm{bc}$ \\
& $\mathrm{P}_{1}$ & $2.04 \mathrm{bcd}$ & $2.05 \mathrm{bcd}$ & $2.157 \mathrm{~b}$ \\
& $\mathrm{P}_{2}$ & $2.124 \mathrm{bc}$ & $2.08 \mathrm{bc}$ & $2.341 \mathrm{a}$ \\
& $\mathrm{P}_{0}$ & $0.869 \mathrm{j}$ & $0.911 \mathrm{j}$ & $1.857 \mathrm{ef}$ \\
$\mathrm{I}_{1}$ & $\mathrm{P}_{1}$ & $1.235 \mathrm{i}$ & $1.26 \mathrm{i}$ & $1.74 \mathrm{f}$ \\
& $\mathrm{P}_{2}$ & $1.49 \mathrm{gh}$ & $1.87 \mathrm{ef}$ & $1.997 \mathrm{cde}$ \\
& $\mathrm{P}_{0}$ & $0.823 \mathrm{j}$ & $0.894 \mathrm{j}$ & $1.57 \mathrm{~g}$ \\
$\mathrm{I}_{2}$ & $\mathrm{P}_{1}$ & $0.914 \mathrm{j}$ & $0.927 \mathrm{j}$ & $1.457 \mathrm{gh}$ \\
& $\mathrm{P}_{2}$ & $1.35 \mathrm{hi}$ & $1.5 \mathrm{gh}$ & $1.82 \mathrm{f}$ \\
\hline $\mathrm{LSD}_{0.05}$ & & \multicolumn{3}{c}{0.158} \\
\hline
\end{tabular}

Means with similar letters are not significantly different at $\mathrm{p} \leq 0.05$ by LSD test.

According to the report of Babaeian et al. (2011) drought stress by reducing plant growth and damage to flowering and grain filling, reduces the grain yield. Significant increases in growth and yield of agronomical important crops in response to inoculation with PGPR have been reported (Sandhya et al. 2010). Rengel and Romheld (2000) reported an increase in wheat grain yields with Fe application. Ghafari and Razmjoo (2013) showed that the foliar application of nano-iron oxide increased antioxidant enzymes activities, chlorophylls content, yield and yield components of wheat. 
The results showed that water limitation reduced yield, chlorophyll index and relative water content of the plants. But the activity of CAT, POD and PPO enzymes, proline content and electrical conductivity increased. Application of PGPR and nano iron oxide also increased grain yield, chlorophyll index, activity of antioxidant enzymes, proline content and relative water content under water limitation conditions, while electrical conductivity decreased. The present results suggested that plants use defensive mechanisms, such as synthesis of antioxidant enzymes and proline to reduce the effects of stress. It seems that the application of PGPR and nano iron oxide can be recommended for profitable yield of triticale under water limitation condition.

\section{References}

Agarwal S and Pandey V 2004. Antioxidant enzyme responses to $\mathrm{NaCl}$ stress in Cassia angustifolia. Biol. Plant. 48: 555-560.

Alexieva V, Sergiev I, Mapelli S and Karanov E 2001. The effect of drought and ultraviolet radiation on growth and stress markers in pea and wheat. Plant, Cell Environ. 24: 1337-1344.

Babaeian M, Tavassoli A, Ghanbari A, Esmaeilian Y and Fahimirad M 2011. Effects of foliar micronutrient application on osmotic adjustments, grain yield and yield components in sunflower (Alstar cultivar) under water stress at three stages. African. J. Agric. Res. 6: 1204-1208.

Bagci SA, Ekizh H, Yilmaz A and Cakmak I 2007. Effects of zinc deficiency and drought on grain yield of field-grown wheat cultivars in Central Anatolia. J. Agron. Crop Sci. 193: 198-206.

Bates LS, Waldren RP and Teare ID 1973. Rapid determination of free proline for water stress studies. Plant Soil. 39: 205-207.

Belimov AA, Dodd IC, Safronova VI and Davies WJ 2009. ACC deaminase containing rhizobacteria improve vegetative development and yield of potato plants grown under water limited conditions. Aspect Appl. Biol. 98: 163-169.

Blakrishman K 2000. Peroxidase activity as an indacator of the iron deficiency in banana. Indian J. Plant Physiol. 5: 389-391.

Blokhina O, Virolainen E and Fagerstedt KV 2003. Antioxidants, oxidative damage and oxygen deprivation stress. Ann. Bot. 91: 179-194.

Che Lah MKB, Nordin MNB, Musliania MI, Khanif YM and Jahan MS 2011. Composting increases BRIS soil health and sustains rice production. Science Asia 37: 291-295.

De La Guardia MD and Alcantara E 2002. A comparison of ferric-chelate reductase and chlorophyll and growth ratios as indices of selection of quince, pear and olive genotypes under iron deficiency stress. Plant Soil 241: 49-56.

De Ronde JA, Cress WA, Kruger GHJ, Strasser RJ and Van Staden J 2004. Photosynthetic response of transgenic soybean plants, containing an Arabidopsis P5CR gene, during heat and drought stress. J. Plant Physiol. 161: 1211-1224.

Dimkpa C, Weinand T and Asch F 2009. Plant-rhizobacteria interactions alleviate abiotic stress conditions. Plant, Cell Environ. 32: 1682-1694.

Gadallah MAA 2000. Effects of indole-3-acetic acid and zinc on the growth, osmotic potential and soluble carbon and nitrogen components of soybean plants growing under water deficit. J Arid Environ. 44:451467.

Ghafari H and Razmjoo J 2013. Effect of foliar application of nano-iron oxidase, iron chelate and iron sulphate rates on yield and quality of wheat. Int. J. Agron. Plant Prod. 4: 2997-3003.

Ghorbanpour M, Hatami M and Khavazi K. 2013. Role of plant growth promoting rhizobacteria on antioxidant enzyme activities and tropane alkaloid production of Hyoscyamus niger under water deficit stress. Turk. J. Biol. 37: 350-360.

Giunta F, Motzo R and Deida M 1999. Grain yield analysis of triticale ( $\times$ Triticosecale, Wittmark) collection grown in a Mediterranean environment. Field Crop Res. 63: 199-210. 
Grover M, Ali SKZ, Sandhya V, Rasul A and Venkateswarlu B 2011. Role of microorganisms in adaptation of agricultural crops to abiotic stresses. World J. Microbiol. Biotechnol. 27: 1231-1240.

Gusain YS, Singh US and Sharma AK 2015. Bacterial mediated amelioration of drought stress in drought tolerant and susceptible cultivars of rice (Oryza sativa L.). African. J. Biotechnol. 14: 764-773.

Jodeh S, Alkowni R, Hamed R and Samhan S 2015. The study of electrolyte leakage from barley (Hordeum vulgare L) and pearl millet using plant growth promotion (PGPR) and reverse osmosis. J. Food Nutr Res. 3: 422-429.

Karo M and Mishra D. 1976. Catalase, peroxidase and polyphenol oxidase activity during rice leaf senescence. Plant Physiol. 57: 315-319.

Kaushal M and Wani SP 2016. Plant-growth-promoting rhizobacteria: drought stress alleviators to ameliorate crop production in drylands. Ann. Microbiol. 66: 35-42.

Kaviani B, Fakouri Ghaziani MV and Negahdar N 2016. The effect of iron nano-chelate fertilizer and cycocel (CCC) on some quantity and quality characters of euphorbia pulcherrima willd. J. Med. Bioeng. 5: 41-44.

Kerkeb L and Connolly EL 2006. Iron transport and metabolism in plants. Genet. Eng. 27: 119-140.

Lalinia AA, Hoseini NM, Galostian M, Bahabadi SE and Khameneh MM 2012. Echophysiological impact of water stress on growth and development of Mungbean. Int. J. Agron. Plant Prod. 3: 599-607.

Miller G, Susuki N, Ciftci-Yilmaz S and Mittler ER 2010. Reactive oxygen species homeostasis and signalling during drought and salinity stresses. Plant, Cell Environ. 33: 453-467.

Nadeem SM, Zahir ZA, Naveed M, Arshad M and Shahzad SM 2006. Variatin in growth and ion uptake of maize due to inculation with plant growth promoting rhizobacteria under salt stress. Soil Environ. 25: 78-84.

Nair AS, Abraham TK and Jaya DS 2008. Studies on the changes in lipid peroxidation and antioxidants in drought stress induced Cowpea (Vigna unguiculata L.) varieties. J. Environ. Biol. 29: 689-691.

Oraki H, Khanjani FP and Aghaalikhna M 2012. Effect of water deficit stress on proline contents, soluble sugars, chlorophyll and grain yield of sunflower (Helianthus annuus L.) hybrids. Afr. J. Biotechnol. 11: 164-168.

Rampino P, Pataleo S, Gerardi C and Perotta AC 2006. Drought stress responses in wheat: physiological and molecular analysis of resistant and sensitive genotypes. Plant, Cell Environ. 29:2143-2152.

Rengel Z and Romeeld V 2000. Differential tolerance to Fe and Zn deficiencies in wheat germplasm. Euphytica. 113: 219-225.

Sadeghipour O and Aghaei P 2012. Response of common bean to exogenous application of salicylic acid under water stress conditions. Adv. Environ. Biol. 6: 1160-1168.

Samarah NH 2005. Effects of drought stress on growth and yield of barley. Agron. Sustainable Dev. 25: 145149.

Sandhya V, Grover M, Reddy G and Venkateswaral UB 2010. Effect of plant growth promoting Pseudomonas spp. on compatible solutes antioxidant status and plant growth of maize under drought stress. J. Plant Growth Regul. 62: 21-30.

Shaharoona B, Arshad M and Zahir ZA 2006. Effect of plant growth promoting rhizobacteria containing ACC-deaminase on maize (Zea mays L.) growth under axenic conditions and on nodulation in mung bean (Vigna radiata L.). Lett. Appl. Microbiol. 42: 155-159.

Singh S, Anjum NA, Khan NA and Nazar R 2008. Metal-binding peptides and antioxidant defence system in plants: significance in cadmium tolerance. In: KHAN NA, SINGH S, (Eds.) Abiotic Stress and Plant Responses, IK International, New Delhi. pp. 159-189.

Szabasos L and Savoure A 2009. Proline: A multifunctional amino acid. Trends Plant Sci. 15: 89-97.

Valentovic P, Luxova M, Kolarovic L and Gasparikova O 2006. Effect of osmotic stress on compatible solutes content, membrane stability and water relations in two maize cultivars. Plant, Soil Environ. 52: $186-191$ 
Wang CJ, Yang W, Wang C, Gu C, Niu DD, Liu HX, Wang YP and Guo JH. 2012. Induction of drought tolerance in cucumber plants by a consortium of three plant growth-promoting rhizobacterium strains. Plos One 7: 1-10.

Zago MP and Oteiza PI. 2001. The antioxidant properties of zinc: Interactions with iron and antioxidants. Free Radicals Biol. Med. 31: 266-274.

Zocchi G, DE Nisi P, Dellorto M, Espen L and Gallina PM. 2007. Iron deficiency differently affects metabolic responses in soybean roots. J. Expt. Bot. 58: 993-1000.

(Manuscript received on 31 December, 2018; revised on 10 April, 2019) 